\title{
Establishing School as a Dialogue Space: A Case Study at Kolese Gonzaga High School
}

\author{
Anggi Afriansyah \\ Research Center for Population, Indonesian Institute of Sciences (LIPI), \\ 12710, Jakarta, Indonesia \\ Corresponding Author: afriansyah.anggi@gmail.com
}

\section{ARTICLE INFO}

\section{Publication Info:}

Research Article

How to cite:

Afriansyah, A. (2020).

Establishing School as a Dialogue

Space: A Case Study at Kolese

Gonzaga High School. Society, $8(1), 48-63$.

DOI : 10.33019/society.v8i1.114

Copyright $@$ (c) 2020. Owned by Author(s), published by Society

\section{OPEN (-) ACcess ç) (i) (2)}

This is an open-access article.

\section{License: Attribution- \\ NonCommercial-ShareAlike (CC BY-NC-SA)}

Received: November 6, 2019;

Accepted: March 9, 2020;

Published: March 31, 2020;

\section{ABSTRACT}

Dialogue is an important part of strengthening democratization. However, dialogue has not been fully practiced and prioritized in schools. Schools become important institutions to promote tolerance and dialogue from various traditions or cultural backgrounds. Strengthening dialogue is an important part of the humanist education approach. This research discussed how Kolese Gonzaga High School established a learning system that provides a large space for dialogue. In each activity, the school tries to develop communication skills, learn to understand each other, and also collaborate with various communities. This research focused on two things: (i) the practice of establishing school as a space for dialogue, and (ii) how school can promote dialogue for peace. This research was qualitative research with a case study approach. Informants were selected using a purposive sampling technique. Meanwhile, the data collection techniques used are in-depth interviews, observation, and literature study. Interviews were conducted with school principals, teachers, students, and parents. Dialogue activities are strengthened in various activities at school. Kolese Gonzaga High School establishes dialogue spaces in various fields in the school such as in classrooms, daily activities, and activities outside of school.
Keywords: Dialogue; Education; Gonzaga; Kolese; High School; 


\section{Introduction}

The Commission for Missing Persons and Victims of Violence (KontraS) mentioned that in the range of October 2016-2017 there were three trends of persecution in speaking out and having opinions (24 cases), intimidation (21 cases), and forced dissolution (19 cases) (Gerintya, 2018). In 2017 the Ministry of Women's Empowerment and Child Protection of the Republic of Indonesia (Kementerian Pemberdayaan Perempuan dan Perlindungan Anak Republik Indonesia or Kemen PPPA) received 15 complaints related to discrimination in schools due to religious differences. Since 2016, according to Kemen PPPA, complaints about discrimination cases have increased (Kuwado, 2017). The cases of persecution and discrimination occur because of differences in belief and political views which then carry over into the domain of education. In fact, the difference is something that is inevitable in the reality of daily life in a pluralistic Indonesia. Violence based on differences in political and religious views is, of course, very worrying for the future of diversity in Indonesia. The role of education in establishing a solid paradigm for students in viewing differences that exist in Indonesia needs to be questioned again. Normatively, schools have a major contribution to internalizing various values. The school is an institution that has a role to construct students' understanding of the social world, as well as being a strategic institution in establishing understanding and practice of Indonesian values, norms, and culture. Diversity in Indonesia requires a type of education that opens space for diverse individuals to learn from one another. The inclusive education model, which is the antithesis of the exclusive education model, is needed by Indonesian children who have different socioeconomic, cultural, and religious backgrounds to establish equal relations in daily activities. This educational model also promotes egalitarian principles; the educational process of this model positions humans in a humane way.

With the condition of the many cases of violence and the lack of a sense of national unity, humane education is very important to be implemented in educational spaces in Indonesia. In practice, humane education promotes dialogue (Freire, 2016). In addition, personal selfdevelopment, self-actualization, and individual freedom are the goals of humanist education (Darim, 2000). Meanwhile, in the context of Indonesians values, referring to Surakhmad (2009), education aims to humanize, civilize, develop the love for the nation, and not merely produce human resources who are ready to use or ready to work in the labor market. Establishing education that promotes dialogue and focuses on humanization is an important task of educational institutions. At this point, the school's position as a locus or domain that makes dialogue an important priority to be established in learning or various other activities. In addition, in a global context, according to Duraiappah (2016) stated that telling young people about violent extremism crime is not enough, so it is necessary to re-education that emphasizes dialogue, critical thinking, and respect for diversity. These three aspects (dialogue, critical thinking, and respect for diversity) are very relevant to be developed through education in schools.

Some research stated that establishing inclusive schools is an important part of the education process, especially in countries that have a multicultural demographic composition. Nishina et al., (2019) suggested that schools could facilitate inclusiveness for ethnic diversity. One important thing that needs to be done is learning that pays attention to multiculturalism and done cooperatively. In addition, one of the important points delivered was that schools need to help students to be ready and able to establish relationships with friends who come from diverse ethnic backgrounds. Thus, education in schools can provide valuable experience and skills to students, which they can bring to the new educational environment, community and workplace. Aloni (2013) mentioned that dialogue as an important part of the development

Copyright (C) 2020. Owned by Author(s), published by Society. This is an open-access article under the CC-BY-NC-SA license.

https://doi.org/10.33019/society.v8i1.114

49 
of humanistic education. Dialogue is important to develop students' sensitivity and abilities. This is their provision to become more autonomous, authentic, moral, and dignified human beings.

Referring to the explanation, establishing dialogue becomes an important part of the social and cultural transformation of diverse Indonesian communities. Dialogue is an important medium for eradicating prejudices among various groups. Dialogue is a bridge to national unity, but it is also an important part of enriching students' perspectives. The communication that is established will erase the prejudice that has existed so far. In the current context, schools that still use anti-dialogue methods, such as using violence to implement a culture of discipline, must immediately be abandoned because it is counterproductive to the future of the Indonesian nation. The increase in persecution carried out by groups of people because of different views is one of the trends that tend to strengthen because they are not accustomed to dialogue in the space of education, with different views either political or religious.

Meetings of students with teachers, school staff, or fellow students with diverse socioeconomic, cultural, and religious status in various educational spaces are valuable learning for students. Through this meeting, students in schools are directed to be accustomed to interacting with various groups. This will be a valuable experience that makes them accustomed when hanging out in the community. The cross-cultural meeting became the basis for establishing dialogue. In the end, dialogue can be considered as a very fundamental requirement for students. Through learning activities and other activities in school, students are accustomed to having an open view and also dare to express their arguments. Daily practice can be through a variety of activities, which have continuity and persistence in school. Dialogue is needed so that students are accustomed to articulating various anxieties through peaceful means, thereby minimizing misunderstanding or even conflict, which will lead to acts of violence. The habit of dialogue in the education space is very crucial and needs to be optimized in daily practices. The habit of dialogue is expected to contribute positively to the democratization process in Indonesia.

This research focuses on one school that has an adequate experience base in establishing dialogue in the education space. Kolese Gonzaga High School in Jakarta, Indonesia, has a long history as a school that pays attention to the process for habituation to dialogue in its educational process. This research illustrates how Kolese Gonzaga High School develops an educational process that provides a large space for habituation to dialogue. Kolese Gonzaga High School is a school with a unique religious base. Catholic religious values are implemented in the daily activities of school. The vision of Kolese Gonzaga High School states clearly, preparing the future leaders who have excellence, competence, responsibility, openness and integrative power in the spirit of services and concern for others and their environment, and should be imbued with the noble of conscience in the spirit of Christianity (SMA Kolese Gonzaga, n.d.). Kolese Gonzaga High School is a school managed by Jesuit of Indonesia Province, who in practice tries to form graduates to have communication skills in the community and understand and appreciate cooperation with fellow people from various backgrounds. Although it is a Catholic-based school, the students, teachers, and staff at Kolese Gonzaga High School come from different religious and ethnic backgrounds. Establishing strong dialogue is one of the focuses of the school. Two profiles of graduates from Kolese Gonzaga High School have become an important basis of school fundamentals for establishing dialogue. The dialogue process is carried out practically in learning and activities at school. This research aims to explain two main things: first, how the practice or implementation of school as 
a space for dialogue, second, how to develop education that is able to promote dialogue as an important part in efforts to negate violence and establish peace.

\section{Literature Review}

Dialogue is one of the central theories proposed by Freire in the context of Critical Pedagogy. According to Freire, the teacher's relationship with students must be in a horizontal position where both are equal subjects. Freire is indeed opposed to the positioning of the teacher as someone who has better knowledge, while students know nothing. The teacher does have a duty to educate students and provide teaching in schools, but in many cases, teachers can also learn from students and learn together with students. The horizontal relationship between the teacher-student starts with dialogue (Monchinski, 2011). In dialogue, the most important thing is the existence of connectedness between the two parties without any prejudice with all statements issued by other parties (Freire in Monchinski, 2011). Thus, a mutual understanding between the two parties will occur.

According to Freire (2016), dialogue is an existential requirement. Dialogue is a form of human gathering, not a form of hostility or war of opinion to seek the truth. Dialogue is a means of shared reflection and efforts to act to change reality. In dialogue, there are processes of communication, knowledge-seeking, and social transformation. Freire \& Shor (1987) revealed:

Through dialogue, reflecting together on what we know and don't know, we can then act critically to transform reality. In communicating among ourselves, in the process of knowing the reality which we transform, we communicate and know socially even though the process of communicating, knowing, changing, has an individual dimension. But, the individual aspect is not enough to explain the process. Knowing is a social event with nevertheless an individual dimension. What is dialogue in this moment of communication, knowing and social transformation? Dialogue seals the relationship between the cognitive subjects, the subjects who know, and who try to know (p. 99).

According to Freire (2016), dialogue cannot take place without a sense of love for the world and fellow human beings as well as humility. The process of learning and doing, creating and changing, and true dialogue will not occur without critical thinking. Dialogue is an arena for human encounters. Without dialogue, there can be no communication and without communication, there can be no true education. Dialogue as essential communication must underlie every collaboration and not try to force, manipulate, tame, and be full of slogans. Dialogists focus on the existing reality and try to answer and change it (Freire, 2016). If it is related to the educational process at school, the teacher must ensure that every student, inside and outside the classroom, feels safe and valued when expressing their aspirations.

Dialogue allows everyone to connect and meet with each other and care for one another. Discussion and dialogue, although not in agreement with what the other party said, Dewey described as a form of cooperative effort in which the two parties can learn from one another (Noddings in Monchinski, 2011). One of the characteristics of democracy is the potential for individual growth through the expression of conflicting opinions and ideas. Dialogue is best understood as a democratic relationship that allows opportunities for mutual understanding with one another and develops by confronting differences rather than 'playing a role' as if such differences do not exist. The important point is not that we always agree on everything that is argued by the other party, but loyalty to every democratic process of freedom expresses every point of view and wants to listen democratically. The better a person understands the opposite 
point of view, the better it is to prepare to fight. Dialogue in the classroom makes this possible (Freire in Monchinski, 2011). The purpose of dialogue is consensus free of coercion, free from all domination (Habermas in Hardiman, 2008). Schools become an important institution to promote tolerance where dialogue from various traditions or cultural backgrounds can still be carried out (Strike, 2008). Strengthening this dialogue is an important part of the emphasis of education which has a humanistic orientation. Haryatmoko (2010) said that there were four goals that became the idealism of education, which consisted of, first, the acquisition of knowledge and skills (competence) or the ability to respond to market demand, second, humanistic orientation, third, responding to social, economic and justice challenges, and fourth, the progress of the sciences themselves. Education is directed to help students to develop their reasoning abilities, take responsibility for their statements, beliefs, and actions. Dialogue is part of intercultural education as an important part of increasing intercultural competence so that children can live together (Huber \& Reynolds, 2014).

Students as part of the community come to class with all kinds of prejudices they bring from family and community. Everything can be criticized and every prejudice that makes other students feel uncomfortable does not get a place in the classroom. Parekh (2001) said that intercultural dialogue plays a crucial role in a multicultural community because each cultural group has a perspective that can be different from other cultural groups, so that dialogue plays an important role. Dialogue is conducted so that each group can understand each other. In a broader context, UNESCO (2008) used dialogue to establish peace. Dialogue is widely used as an important tool for achieving peace. In addition, Information and Communication Technology (ICT) and various media can be used to encourage dialogue, mutual understanding, self-expression, peace, and reconciliation. Spinner-Halev (2003) stated that schools that have diverse students have the opportunity to learn from one another in daily practice, not just limited to the theory in the book. In this context, the variety of schools becomes a very relevant space for a variety of dialogues to get to know one another.

Establishing school as a dialogue space also needs to pay attention to the position of the school where the diversity of differences is something that must be managed properly. In this context, multicultural education becomes relevant in the process at school. In the context of multicultural education, Banks (2004) stated that there are several dimensions, consisting of (1) content integration, (2) the knowledge construction process, (3) prejudice reduction, (4) an equity pedagogy, and (5) empowering school culture and social structure.

First, content integration, related to how teachers use examples and content from various cultures and groups to illustrate key concepts, principles, generalizations, and theories, in their fields or disciplines. There are more opportunities for the integration of ethnic and cultural content in some subject areas than in others. In social studies, language arts and music, frequent and sufficient opportunities exist for teachers to use ethnic and cultural content to illustrate concepts, themes, and principles. Then, there are also opportunities to integrate multicultural content into mathematics and science. However, the opportunities are not as extensive as in social studies, language arts, and music.

Second, the knowledge construction process, related to the extent to which the teacher helps students to understand, investigate, and determine how implicit cultural assumptions, reference frames, perspectives, and biases in a discipline affect the way in which knowledge is established in it. Third, prejudice reduction, which seeks to help students develop positive attitudes toward different racial, ethnic, and cultural groups. Fourth, equity pedagogy is when teachers modify their teaching to facilitate the academic achievement of students of diverse races, cultures, genders, and social class groups. Fifth, empowering school culture and social

Copyright ( $(2020$. Owned by Author(s), published by Society. This is an open-access article under the CC-BY-NC-SA license. https://doi.org/10.33019/society.v8i1.114 
structure, related to the culture and organization of schools that promote gender equality, race and social class must be a concern for every element in the school. School culture must be able to empower students from racial and ethnic groups or gender.

\section{Research Methodology}

This research used a qualitative research method with a case study approach. Case studies are chosen to carefully investigate each program, event, activity, process or group of individuals whose time and activities are limited (Cresswell, 2006). For this research, it is specifically limited to (1) how Kolese Gonzaga High School establishes a dialogue space at school, (2) How programs, activities, and processes enable students to engage in various dialogues at school. Interviews were conducted with school principals, vice-principals, teachers, parents, and students to find out their perspectives on the school's efforts to establish dialogue and all its problems. Informants were selected using a purposive sampling technique. Meanwhile, the data collection techniques used are in-depth interviews, observation, and literature study. The three techniques are used to get in-depth information related to the daily practices of all actors in the school to establish dialogue. Some of the data from this paper used data from thesis research ${ }^{1}$. To update the data, a series of interviews and observations were conducted in July-August 2018.

\section{Results and Discussion}

\section{A. School Practice as a Dialogue Space: The Kolese Gonzaga High School Case}

Kolese Gonzaga High School is a Catholic-based school. In the school's vision, the identity of Kolese Gonzaga High School as a religious-based school is clearly stated. "Preparing the future leaders who have excellence, competence, responsibility, openness and integrative power in the spirit of services and concern for others and their environment, and should be imbued with the noble of conscience in the spirit of Christianity" (SMA Kolese Gonzaga, n.d.). Although as a Catholic-based school, from the beginning, Kolese Gonzaga High School opened a space or opportunity for students, teachers, and employees, who are non-Catholic to study and work. From the school administration records, the teachers, administrative staff, and students in the school come from various religious backgrounds including Christianity, Islam, Sikhism, Baha'i Faith, Buddhism, and Hinduism. From the start, Kolese Gonzaga High School tried to be an inclusive school that opened up the opportunity for anyone to become a student or work. The openness attracted a variety of parents from various religious and ethnic backgrounds to get their children into Kolese Gonzaga High School. For example, parents of students who have Islamic backgrounds, entrust their children's education to Kolese Gonzaga High School, due to the school's discipline in learning and other activities.

"Discipline issues. That, number one. (Besides that) because we were students at a Catholic school in the past"(Interview with parents of Kolese Gonzaga High School students, May 9, 2013, as cited in Afriansyah, 2014).

This condition made the parents of students decide that one of their children would register as a student at Kolese Gonzaga High School. Another reason is the historical experience of parents of students who have been educated by Catholic-based schools. Both agreed that the

1 Afriansyah 2014

Copyright $($ 2020. Owned by Author(s), published by Society. This is an open-access article under the CC-BY-NC-SA license. https://doi.org/10.33019/society.v8i1.114 
quality of education in Catholic-based schools was very good, so they chose Kolese Gonzaga High School as their children's school.

Kolese Gonzaga High School has students with different religious and cultural backgrounds. These conditions allow for intensive dialogue at school. In addition, the Seminarians or prospective Pastors who attended education at Wacana Bhakti Seminary were also students at Kolese Gonzaga High School, making the variety of students in the school more diverse. According to the Head of Kolese Gonzaga High School, the merging of seminarians and female students aims to create conditions so that prospective Pastors gain experience of interacting with various groups in the school. Hopefully, the prospective Pastors at the time of carrying out their duties when in the community later did not experience awkwardness. Referring to school history, the integrating of male and female students at Kolese Gonzaga High School began in 1990. Initially, Kolese Gonzaga High School was a school that specifically accepted male students but later accepted female students. The amendment to the regulation aims to provide a natural feel for teenagers for Seminarians and Kolese Gonzaga high school students in general (SMA Kolese Gonzaga, n.d.b). For seminarians, it is expected that since the early education process it is not awkward to interact with women. For the students, it is expected that since the early education process they can have a normal interaction. The process of merging and integrating male and female students aims to make prospective religious leaders more familiar with their congregants and not feel exclusive (Afriansyah, 2014).

The school's openness to various views in the community is summarized in the four and five point graduate profiles on the Kolese Gonzaga High School website. Point four mentions "to have communication skills in the community", and point five mentions "to have understanding and could appreciate cooperation with others within different backgrounds" (SMA Kolese Gonzaga, n.d.a). These two profiles are important fundamentals for dialogue practice in school. Based on the awareness of diversity in the community, the school seeks to make its students have adequate communication and be able to respect different groups.

To make students, who have communication skills in the community and understanding and could appreciate cooperation with others within different backgrounds, certainly require adequate understanding and direct practice. This ability is not present suddenly but through a process of continuous strengthening in school, both in the learning process and activities outside the classroom. Dialogue needs to be accustomed to in every process at school. Communication and efforts to understand each other cannot be formed without a routine and familiar dialogue process in every activity undertaken, either in the learning process or in daily activities at school.

The process of establishing dialogue space in schools is seen in the efforts of schools to establish egalitarian cultures. Egalitarian culture establishing's felt in daily activities at Kolese Gonzaga High School. Although with a unique and specific culture, egalitarian culture was also established in schools managed by the Jesuit of Indonesia Province, such as in Kolese De Britto, Yogyakarta, Kolese Loyola, Semarang, and Kolese Kanisius, Jakarta. Egalitarian school culture was developed with the aim of establishing equal relations among all elements in the school. Then, it is hoped that each element understands their respective roles and responsibilities in both learning and other activities and the school establishes open dialogue spaces. For example, in the learning process, students are given the opportunity to express various arguments freely and are not disputed if they have different views with the teacher. In learning history, for example, the teacher provides various perspectives. In history lessons, there are so many perspectives on looking at an event (Afriansyah, 2014). In each lesson, each student is given space to provide a view based on the knowledge students have, likewise in learning in other

Copyright ( $(2020$. Owned by Author(s), published by Society. This is an open-access article under the CC-BY-NC-SA license.

https://doi.org/10.33019/society.v8i1.114

54 
fields. It aims to make students accustomed to being active and dare to express any arguments that are considered true. They are directed to become accustomed to dialogue with teachers and fellow students on various issues. If there are differences of opinion, they try to find a way to resolve it. Dialogue is put forward to solve every problem.

Beyond learning, there are a number of activities aimed at strengthening dialogue habits and resolving common problems. A forum was formed to resolve the problems that exist in school. The forum is called Force Forum. One case that appeared and discussed together was for example when a student was caught cheating. Cheating is something that is strictly forbidden in Kolese Gonzaga High School. The rules stated that students cheating during daily tests and general tests will be subject to sanctions by giving the lowest test score (0) by the teacher. In addition, students will also be given a Warning Letter, and then parents will be called by the school. Dialogue will be conducted through the Student Force Forum so that there are no more students cheating. Another example where dialogue becomes an important part of school activities is when there are student protests regarding the rules of student hair length. Initially, students who had an average value of 80 had the privilege of hair lengthening. But suddenly there was a rule that the average grade of students must be 85 . Students then protested related to these rules and delivered it straightforwardly to the school. The school appreciates the protest because they dare to express their rights; it is very important (Afriansyah, 2014).

In the context of teacher and student relations, there are sarasehan (informal gatherings/forum) as a form of communication between the two parties. Sarasehan was a typical event from the school. In this activity, the teacher, staff, and students have an equal position and hold a dialogue to express the problem and how to solve $\mathrm{it}^{2}$. Students get the opportunity to express their criticisms and suggestions directly to the school management and teachers. Criticisms and suggestions delivered can be related to teacher learning patterns, assessment systems, or related to school facilities. Any complaints are expressed openly to teachers and staff. Students are also invited to dare to communicate anything that they think is inappropriate and needs to be corrected immediately. Criticisms and suggestions to homeroom teachers, teachers, or head of school must be conveyed openly. It aims to solve problems in a fast and appropriate way. In essence, students can freely evaluate education services in school. Of course, these criticisms and suggestions must be justified. This spirit of sharing and openness is established on a family basis so that the party that was criticized did not feel personally attacked. The spirit that was established was the desire to continuously improve the quality of education services in Kolese Gonzaga High School.

For a broader scope, there are a variety of activities that strive to strengthen students' understanding of diversity and the regularity of dialogue with various groups, among others through the activities of Jamboree, Live-in, and social services for the community. Students who are involved in this activity will deal directly with various realities in the community. Jamboree activities carried out in nature at the beginning of the new student period (Class 10) are aimed at students getting to know themselves, and understand other people. The school believes that student activities carried out in nature will emerge the original character of each individual; the originality of each self will be present in advance. Through this program, there are internal and external dialogue processes. Living together in nature with a variety of different properties will make students try to understand each other. From this program, students are educated to become individuals who know themselves, are not easy to complain, want to work together,

2 Interview with Kolese Gonzaga High School teacher, May 24, 2018, at Kolese Gonzaga College High.

Copyright (C 2020. Owned by Author(s), published by Society. This is an open-access article under the CC-BY-NC-SA license. https://doi.org/10.33019/society.v8i1.114 
and serve others. From Jamboree's activities, in addition to dialogue with oneself, students also try to dialogue with nature and the environment. When participating in the Live-in activity, Class 10 students have the opportunity to live in homes of residents who have different economic status, culture, religion, and way of life. Students directly interact with the community to be able to communicate and understand the variety of social life. This condition allows students not to be awkward when dealing with diversity when they are involved in the community. Through Live in activities, students are invited to dispel the prejudices that have been on their minds so far and immediately prove them in the community they live in for several days. Meetings between students and residents are an important part of experiencing people's daily lives that are very different from their daily backgrounds.

Likewise in social service activities, students provide assistance to those who are considered economically disadvantaged. They organize social service activities ranging from data collection to handing out aid to the community. From interviews with students, even though they intend to help, there are times when they are rejected by the community. Moreover, they come from Catholic-based schools, while the majority of people who are helped are Muslim. Social service activities are then considered by the community as part of religious missions. Many people still consider this activity to be part of Christianization. In the process, as revealed by students, they learn about religious differences that are an issue in the community. Students then learn to become excellent negotiators. Students try to explain in detail the purpose of the school's social service to the community. Students practice to communicate the aims and objectives of social service programs. Students get an understanding of the differences that occur in the community, not just learning theories in school ${ }^{3}$.

The activities carried out by the school show the process of establishing a dialogue that is designed in a systematic and planned manner. The various activities carried out become part of establishing an egalitarian school culture, with teachers and students who have the same position in accordance with their respective capacities and most importantly by prioritizing responsibilities. In addition, daily activities serve as an example of the seriousness of schools in establishing the foundation of egalitarian culture. For example, the habit of riding with one another in a vehicle when going home from school becomes a concrete manifestation of establishing a strong family and egalitarian culture. Students who have a vehicle will invite other students to come home together. Here a sense of kinship is established, which is not only limited to formalism but also to direct practice. Schools try to establish a sense of family and egalitarianism in various aspects. In school organizations like Student Council (Organisasi Siswa Intra Sekolah or OSIS), each student is given the opportunity to become a member or leader of the organization regardless of their religious background. As revealed by Head of Student Council of Kolese Gonzaga High School:

"In my opinion, at Gonzaga College High School, there is diversity. So in all spaces such as extracurricular activities, group activities, and organizations, never mentioned a single issue about ethnicity. So we are free to do everything" (Interview with the Head of Student Council of Kolese Gonzaga College High School, May 8, 2013, as cited in Afriansyah, 2014).

The school establishes a sense of "free responsibility" for each student. This means that the space for freedom of each individual is limited by the freedom of other individuals in the

${ }^{3}$ Interview with three Kolese Gonzaga High School students, May 24, 2018, at Kolese Gonzaga High School.

Copyright $($ 2020. Owned by Author(s), published by Society. This is an open-access article under the CC-BY-NC-SA license. https://doi.org/10.33019/society.v8i1.114 
school. This has been given since the beginning of the new student orientation. Students are given the understanding that they can do a variety of things but may not violate the rights of others. Students are given space to explore themselves personally and take responsibility for their choices. A unique example is male students who have achievements, are free to have long hair with the requirements students must have a report card with a good average grade. This freedom is an appreciation from the school if students can take responsibility for their academic achievement.

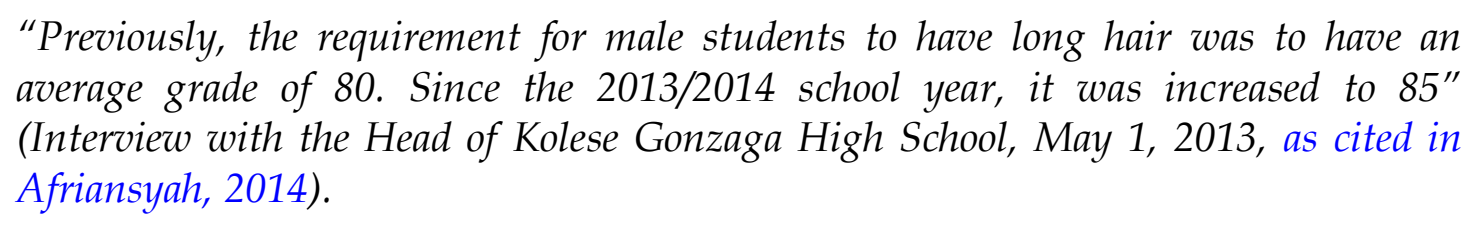

The process of establishing dialogue in schools, as stated by Freire (2006), requires a sense of mutual understanding and equality. Teachers and students must be in an equal position and have a strong desire to listen to each other carefully. Dialogue must promote mutual respect and love. The relationship formed in Kolese Gonzaga High School, if referring to Banks (1993), is part of an effort to establish an Equity Pedagogy. The equity pedagogy seeks to provide equal opportunities for every student who has diversity. Their position is equal in the learning process at school. Through some of its programs, schools also try to establish prejudice reduction or erode various prejudices that usually occur because of differences in ethnic identity, religious or social (Banks, 1993). Through its various programs, the school trains diverse students with the aim that students can interact and participate equally. Students are invited to build an appreciation of differences, both in schools and in the community.

As stated by Spinner-Halev (2003), schools that have diverse students have the opportunity to learn from one another directly in various daily activities through practices, not just limited to the theory in the book. It enables each student to learn how to work together with different individuals. Referring to Freire (2016), the school also seeks to establish equal relations between each individual, thus enabling dialogue. Equal relations are the starting point for constructive dialogues. There is no distance between the teacher and students as well as between students and students at various levels. There is a special space provided by the school that allows each individual to express their aspirations or opinions.

In the dialogue process, referring to Noddings in Monchinski (2011) each individual in the school can relate and meet with each other and care for one another. There are problems in schools that require solving together so that each individual must participate to express their aspirations. Programs established in the school show the school's efforts to create a space for dialogue. In the midst of the administrative and academic burdens of school, the practice of establishing school as a dialogue space becomes a complicated matter. So the school's effort to build a dialogue space is very crucial.

\section{B. Promoting Dialogue against Violence: Efforts to Establish Peace in Multicultural Communities}

Peace is the universal goal or ideals of society, a safe and peaceful world and far from violent conflicts. But today, conflicts in various countries, especially violence based on religion or ethnicity are still prominent. It all happened because each group did not have an awareness of the importance of establishing a peaceful world. In addition, problems of social inequality, suspicion, and lack of locus to meet and understand each other are increasingly limited. In the 
Indonesian context, for example, at the time the Presidential or Legislative Election or Regional Head Elections take place, it is very easy to see disputes using various justifications. Different parties are enemies that must be eliminated. This condition is very worrying. Efforts to establish a peaceful society are difficult to do as conditions continue to occur. One aspect that is an important locus to establish a tradition of dialogue to create peace is through education. Article 26 point 2 of The Universal Declaration of Human Rights stated:

Education shall be directed to the full development of the human personality and to the strengthening of respect for human rights and fundamental freedoms. It shall promote understanding, tolerance, and friendship among all nations, racial or religious groups, and shall further the activities of the United Nations for the maintenance of peace (United Nations, n.d.)

Article 26 point 2 of the Universal Declaration of Human Rights mandates crucial issues for education to develop people who respect Human Rights. Education needs to promote mutual understanding, tolerance, and brotherhood among all humanity. Education has a central role in helping to realize the central goal of participatory democracy: encouraging people responsibility, participatory, and oriented towards justice (Westheimer \& Kahne, 2004 in Kester \& Booth, 2010). Freire holds that education has the potential to establish a better world. Dialogue with an equity pedagogy basis and compassion is an important part of establishing education (Kester \& Booth, 2010). Schools are an important part of establishing that commitment. Without the vision and mission of the school and adequate programs, the process of internalizing these values becomes very difficult to implement.

Establishing dialogue becomes part of the learning process and daily activities at Kolese Gonzaga High School. The school seeks to familiarize students to engage in dialogue when they face various problems in daily activities. Important decisions in schools are achieved through constructive dialogue. Dialogue practices are carried out to reach mutual agreement and understanding. When there are problems related to various policies in schools that are not appropriate, students are given the opportunity to question the policies released by the school. Students in the forum are given the opportunity to dialogue and question various policies that students criticize with teachers or school leaders. As one informant revealed:

"It's opened. There is such a thing as a forum. For example, in the previous case, the Minimum Completion Criteria was raised for students who had long hair to be 85. However, many students protested, especially male students. Finally, this problem was mediated through the forum, although there were no changes. This is fair because we know the reason. We also give a lot of opinions to the authorities and get responses, although sometimes it takes a long time. There are conflicts that have occurred, but this method is better because we know the purpose of the policy" (Interview with Student, April 28, 2013, as cited in Afriansyah, 2014).

The habit of conducting dialogue in the learning process and school activities is an important part of increasing their capacity. Through discussions such as the implementation of forum activities, awareness about the process of dialogue in an effort to solve each problem becomes a priority. This kind of activity becomes a school effort to develop students who prioritize dialogue in solving various problems. Efforts to establish awareness for every student that dialogue is something that needs to be prioritized compared to the use of violence to solve

Copyright ( $(2020$. Owned by Author(s), published by Society. This is an open-access article under the CC-BY-NC-SA license.

https://doi.org/10.33019/society.v8i1.114

58 
every problem in daily life. Through learning activities, awareness of daily social reality can be established. The teachers consciously establish an understanding for students that Indonesia is a diverse society. A teacher stated that Kolese Gonzaga High School is a "mini Indonesia". Teachers also raise a variety of daily problems or actual issues become one part of the learning process. According to the teachers, awareness about Indonesia which is a diverse country and not only built by one group is an important thing that students need to realize. Indonesia is a joint work of various elements consisting of ethnicity, nation, religion, and social class. The solid delivery of material and practices about the diversity of society in Indonesia makes the understanding of the diversity of Indonesia fully appreciated by all elements in the school. The framework of understanding the national and Indonesian frame becomes an important part of establishing education in schools. The History Teacher, who has taught at the school for decades, states that:

"Students and teachers, so here, non-Catholics are not only students but also their teachers and staff. We have a frame that this is a mini Indonesia in an educational institution. That's what we want to develop. So it is hoped that later the output from this school will really bring Indonesia like that which is diverse, and then don't have the view that Indonesia consists only of group $A$ or group $B$, this is something that denies history" (Interview with History Teacher, April 26, 2013, as cited in Afriansyah, 2014).

The notion of diversity and Indonesian values is not only knowledge gained in schools but also in daily practices at school. In addition, dialogues in the classroom are conducted to explore students' basic knowledge and understanding of an issue regarding the actual issues in the community. The teacher raises cases as an effective learning tool about the reflection of appreciation for the existence of diversity in Indonesia. Through learning and non-learning activities, the building of theory and practice that is very important for multicultural Indonesian society is internalized. In building a society that can respect each other's differences, establishing dialogue is an effort to make Indonesia more peaceful and harmonious. With diverse backgrounds in terms of ethnicity, nationality, social class, or religion, the willingness between different groups to dialogue for mutual understanding or in resolving conflicts will make life more beautiful. The dialogue will minimize the conflicts that exist in society because dialogue is built on the basis of mutual trust. An equal position between groups of people will make it easier for dialogue between people. Hopefully, peace will be easier to realize. According to the Principal, it is very important for students to have a mutual understanding. Every individual will always try fairly to find out why other people do certain actions. Students need to be invited to think clearly and not to guess negatively the reasons other people act.

\begin{abstract}
"Students are educated to always understand other people, why others act that way, why others act this way. If there is violence here and there, usually we will find out, and try to understand why they are doing it. Usually like that. Oh right, they do it because of their past experiences, for example being bullied. No wonder, when possible, they will feel this is the right time to take revenge" (Interview with the Head of Kolese Gonzaga High School, May 2, 2013, as cited in Afriansyah, 2014).
\end{abstract}

Strengthening the habituation of dialogue through practices in schools is an important basis for strengthening the capacity of students in the future. Students feel that the school 
accommodates various criticisms expressed by students. The egalitarian culture constructed in schools allows students to freely express their aspirations critically. Students feel that the habituation has made them have a critical perspective on various issues. In addition, they have a broad perspective on various problems that exist in society. The moment of the Regional Head Elections in Jakarta, for example, they were criticized because public spaces in their daily lives became very uncomfortable because they were dominated by political issues. The polarization that occurs makes them embarrassed. Moreover, the hoax news and efforts to divide this nation were felt. In students 'views, political issues that include religious justification, to corner different parties' political views are not very good ${ }^{4}$.

Not only in school but strengthening dialogue is also carried out by parents at home. One parent stated that children are given space to do various activities, but they must take responsibility for their choices. The process is carried out through dialogue between parents and children.

"What are the benefits? We must know the responsibility. Parents only agree if it is already good to do. That's all. Because what is basically, children will talk to parents if they are hesitant to decide, as long as they give a good understanding of what they do. Let the children experience it themselves because if they don't they will not grow up" (Interview with Parents, May 9, 2013, as cited in Afriansyah, 2014).

In addition to establishing dialogue in schools, various activities undertaken by schools greatly contribute to students' perspectives on violent activities. Various activities in the school will reduce the stress level of students because they have positive activities. Meanwhile, there are still many students out there who are trapped in violent activities such as brawls, because schools do not provide adequate actualization space for their students. One parent said:

"In the government-run high schools or vocational schools often fights, (using violence). It's one of the stress levels because the expression is not accomplished. In Gonzaga, there are a lot of activities that can put these children's emotions into something positive" (Interview with Parents, May 9, 2013, as cited in Afriansyah, 2014).

Based on these findings, it is increasingly clear that the vision of schools is a crucial part of making dialogue as an effort to solve every problem. Dialogue is carried out to minimize the practices of violence that occur in various parts of the world through education. The vision to be a school as a space for dialogue, schools must recognize that each element (actor) in the school has an equal position. The vision, mission, and core values that are referred to in schools are then practiced in daily activities, so there is no difference between normative and implementation. The position of the school to build a dialogue space is very significant in the context of the multicultural community. The habit of dialogue in the classroom is an attempt to negate any violence that might occur. This can also be an effort to build peace in Indonesia. Strengthening the theory and practice carried out at Kolese Gonzaga High School is in line with Parekh's views regarding the multicultural curriculum. A multicultural curriculum, according to Parekh (2001), must meet two conditions. First, it can't be too narrow. Curriculum content in multicultural education must be able to provide a clear understanding and be able to stimulate students in asking questions, arouse curiosity, encourage their sympathies, and help them to

${ }^{4}$ Interview with three Kolese Gonzaga High School students, May 24, 2018, at Kolese Gonzaga High School.

Copyright $($ 2020. Owned by Author(s), published by Society. This is an open-access article under the CC-BY-NC-SA license. https://doi.org/10.33019/society.v8i1.114 
appreciate differences and human diversity. In addition, students must get a variety of perspectives about an event, and then be able to explore sensitivity, moods, and reflect on enthusiasm. Second, the teaching must be right. The curriculum content must also contain dialogues in various cases to get students' responses to assessing different problems. Meanwhile, referring to the concept of multicultural curriculum, according to Banks (1993), through the learning process in the classroom, knowledge is constructed and reflected on the basis of interest and experience, it is important for students to interpret and bridge the cultural differences that exist in society.

Each of these incidents certainly does not have a single history and certainly has a different narrative. Establishing dialogue in schools requires structured and systematic work. Learning in schools becomes very important to internalize students, both paradigmatically and practically, the solution to each problem can be discussed together through dialogue. Awareness for every element in the school regarding the diversity of Indonesia, consisting of ethnic, religious, linguistic, social class, and different political views, is very important. Recognition of heterogeneity and diversity in Indonesia is an important form of appreciation in a multicultural society (Kymlicka, 1995). In terms of normative, dialogue contains equality, trust, respect, and also empathy. The quality of trust and empathy must be developed through dialogue (Head, 2012). Schools, as stated by each informant, become a space for the introduction of diversity in the community. In addition, through education in schools, students get the opportunity to build perspectives to be more open to various perspectives that exist in the community.

\section{Conclusions}

Schools as a dialogue space are a necessity that needs to be built in the education process and become a school culture. This effort, which started from an educational institution, became one of the reinforcements of a positive national narrative by promoting equal communication between individuals. Dialogue is not an easy thing to do, so it needs to be trained and accustomed. The learning space and other activities in the school become a space where the dialogue is conducted. Equality between students becomes important to strengthen the establishment of egalitarian culture and has become a school culture so that Kolese Gonzaga High School becomes a school that practices dialogue in its daily activities. Establishing dialogue means trying to trust each other and continues to learn from each other and listen to diverse views. The effort established from this school is expected to contribute to the establishment of social relations in the community. Mutual trust and acceptance that everyone is equal will negate conflict. There is already an effective mechanism which is the use of dialogue rather than using violence. Establishing dialogue in a multicultural society is one of the important efforts in strengthening national ties in the diversity of Indonesia.

\section{Acknowledgment}

The author would like to thank Dr. Cahyo Pamungkas, S.E., M.Si., Coordinator of National Priorities Research Program, Study of Intolerance and Radicalism in Indonesia, organized by the Deputy for Social Sciences and Humanities, Indonesian Institute of Sciences (LIPI), in 2018, which provides flexibility for the writer to conduct research and use some of the data in that research. The author also wishes to thank all the informants who provided information during this research conducted. 


\section{References}

Afriansyah, A. (2014). Internalisasi Multikulturalisme di Sekolah (Studi Komparatif di SMA Islam Al Izhar Pondok Labu dan SMA Kolese Gonzaga) (Master's thesis). Depok: Universitas Indonesia.

Aloni, N. (2013). Empowering dialogues in humanistic education. Educational Philosophy and Theory, 45(10), 1067-1081. https:/ / doi.org/10.1111/j.1469-5812.2011.00789.x

Banks, J. A. (1993). Multicultural Education: Historical Development, Dimensions, and Practice. Review of Research in Education, 19, 3-49. Retrieved from www.jstor.org/stable/1167339

Banks J. A. (2004) Teaching for Social Justice, Diversity, and Citizenship in a Global World, The Educational Forum, 68:4, 296-305, https://doi.org/10.1080/00131720408984645

Cresswell, J. W. (2006). Qualitative Inquiry and Research Design: Choosing Among Five Approach (Second ed). London: Sage Publications.

Darim, D. (2000). Humanistic Values Education: Problems and Possibilities. In M. Leicester et al., (Eds.), Politics, Education and Citizenship (Vol. IV). London: Falmer Press.

Duraiappah, A. K. (2016, 10 10). Open dialogue in schools is the first step in fighting violent extremism. Retrieved 2 17, 2020, from theguardian.com: https:/ / www.theguardian.com/global-development-professionalsnetwork/2016/oct/10/peace-education-preventing-violent-extremism-unesco

Freire, P., \& Shor, I. (1987). A pedagogy for liberation: Dialogues on transforming education. London: Macmillan Education LTD. https://doi.org/10.1007/978-1-349-18574-0

Freire, P. (2016). Pendidikan Kaum Tertindas (Translated ed.). Jakarta: LP3ES.

Gerintya, S. (2018, 5 10). Aksi-Aksi Persekusi yang Mengancam Indonesia. (M. S. Handayani, Editor) Retrieved 10 1, 2018, from tirto.id: https://tirto.id/aksi-aksi-persekusi-yangmengancam-indonesia-cJ9Q

Hardiman, F. B. (2008). Menuju Masyarakat Komunikatif: Ilmu, Masyarakat, Politik, dan Posmodernitas menurut Jurgen Habermas. Yogyakarta: Kanisius.

Haryatmoko, J. (2010). Dominasi penuh muslihat: akar kekerasan dan diskriminasi. Jakarta: Gramedia Pustaka Utama.

Head, N. (2012). Transforming conflict: Trust, empathy, and dialogue. International Journal of Peace Studies, 33-55. Retrieved from www.jstor.org/stable/41853034

Huber, J., \& Reynolds, C. (2014). Developing intercultural competence through education (Pestalozzi Series No. 3 ed.). Strasbourg: Council of Europe Publishing.

Kester, K., \& Booth, A. (2010). Education, peace and Freire: A dialogue. Development, 53(4), 498-503. https://doi.org/10.1057/dev.2010.86

Kuwado, F. J. (2017, 7 17). Menteri PPA Sebut Ada 15 Laporan Diskriminasi di Sekolah karena Beda Agama. (S. Asril, Editor) Retrieved 10 1, 2018, from kompas.com: https:/ / nasional.kompas.com/read/2017/07/17/18441521/menteri-ppa-sebut-ada-15laporan-diskriminasi-di-sekolah-karena-beda-agama

Kymlicka, W. (1995). Multicultural Citizenship: A Liberal Theory of Minority. New York: Oxford University Press Inc.

Monchinski, T. (2011). Engaged Pedagogy, Enraged Pedagogy: Reconciling Politics, Emotion, Religion, and Science for Critical Pedagogy. Rotterdam: SensePublishers. https:/ / doi.org/10.1007/978-94-6091-448-5

Nishina, A., Lewis, J. A., Bellmore, A., \& Witkow, M. R. (2019). Ethnic diversity and inclusive school environments. Educational Psychologist, 54(4), 306-321. https:// doi.org/10.1080/00461520.2019.1633923 
Parekh, B. (2001). Rethinking multiculturalism: Cultural diversity and political theory. Ethnicities, 1(1), 109-115. https:/ / doi.org/10.1177/146879680100100112

SMA Kolese Gonzaga. (n.d.). Core Values. Retrieved 10 10, 2018, from gonzaga.sch.id: https://www.gonzaga.sch.id/en/visi-misi/

SMA Kolese Gonzaga. (n.d.). History of Gonzaga Collage. Retrieved 10 10, 2018, from gonzaga.sch.id: https://www.gonzaga.sch.id/en/history/

Spinner-Halev, J. (2003). Extending Diversity: Religion in Public and Private Education. In K. Will \& N. Wayne (Eds.), Citizenship in Diverse Society. New York: Oxford University Press.

Strike, K. A. (2008). Civil society and schooling: Particularistic voices and public spaces. In H. D. Meyer, \& W. L. Boyd (Eds.), Education Between State, Markets, and Civil Society (Comparative Perspectives ed.). New Jersey: Lawrence Erlbaum Associates.

Surakhmad, W. (2009). Pendidikan Nasional: Strategi dan Tragedi. Jakarta: Penerbit Buku Kompas.

UNESCO. (2008). UNESCO's Work on Education for Peace and Non-Violence. Retrieved from unesco.org: https://unesdoc.unesco.org/ark:/48223/pf0000160787

United Nations. (n.d.). Universal Declaration of Human Rights. Retrieved from https://www.un.org/: https://www.un.org/en/universal-declaration-human-rights/

\section{About the Author}

Anggi Afriansyah, obtained his Magister Degree from Department Sociology, Faculty of Social and Political Sciences, University of Indonesia, in 2014. The author is a researcher at Research Center of Population, Indonesian Institute of Sciences (LIPI), a government agency that has the main duties in improving the science-development activities through basic and applied research activities, with areas of expertise in the field of demography. His research interests include education and labor issues.

E-Mail: afriansyah.anggi@gmail.com 